AIFININANE

\title{
PERFORM ANCE AND CARCASS CHARACTERISTICS OF GROWING RABBITS FED BACTERIAL PROTEIN MEAL
}

Fatufe $\mathrm{AA}^{1^{*}}, \mathrm{M}$ atanmi $1 \mathrm{O}^{2}$ and $\mathrm{AO}$ Alalade ${ }^{2}$

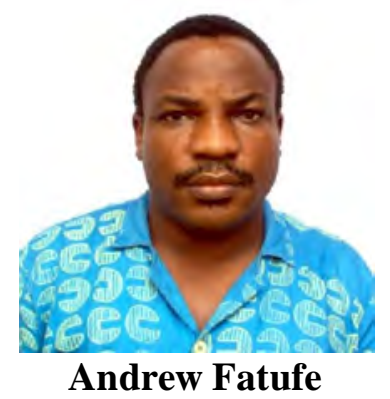

*Corresponding author email: aafatufe@oauife.edu.ng or andrewfatufe@yahoo.com

${ }^{1}$ Department of Animal Sciences, Obafemi Awolowo University, Ile-Ife, Nigeria.

${ }^{2}$ Adoms Nigeria Enterprises, Ibadan, Nigeria. 


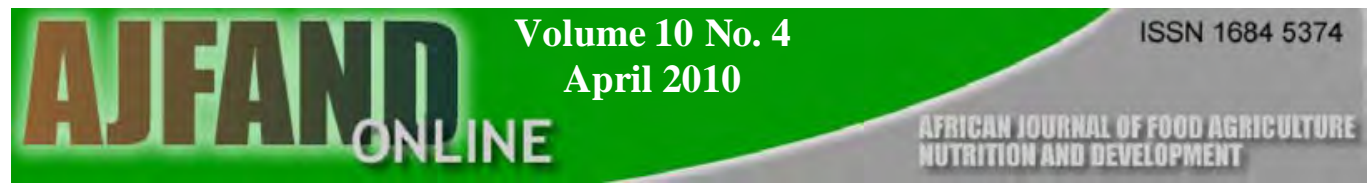

\section{ABSTRACT}

In an 84 days feeding trial, the effect of feeding bacterial protein meal (BPM) either as a replacement for fish meal or for groundnut cake meal in growing rabbits was examined. A total of 20 growing rabbits having an initial body weight of 617.2 (standard error 25) g were randomly assigned to five dietary treatments. A control diet based mainly on agro-industrial by-product palm kernel meal was formulated to meet the nutrient requirement of growing rabbits. Other conventional protein and energy rich ingredients such as maize, groundnut cake (GNC) and fish meal (FM) were included as composite at levels up to $17 \%$ of the weight. Bacterial protein meal (Streptomyces sp., species not specified by the manufacturer) with a crude protein, fat and fibre content of $70,6.5$ and $4.1 \%$, respectively was added to the control diet (diet I) either as a replacement for FM at 0,20 and $40 \mathrm{~g} / \mathrm{kg}$ in diets I, II and III or as a replacement for GNC at 34 and 68 $\mathrm{g} / \mathrm{kg}$ in diets IV and V, respectively. Each diet was offered to four rabbits housed individually in raised metal hutches with wire screen floors with each hutch representing an experimental unit. The rabbits were individually weighed on a weekly basis until the end of the experiment. Water and feed were supplied ad libitum and daily voluntary feed intake was monitored. Growing rabbits responded non-significantly ( $\mathrm{p}>0.05)$ in feed intake, body weight gain and feed conversion to BPM as a replacement for either FM or GNC over the 84 days of experiment. Six rabbits (3 rabbits from each treatment) on diet I (zero inclusion of BPM) and diet V (highest level of BPM inclusion) were slaughtered at 12 weeks to determine carcass composition. The inclusion of BPM in diet V reduced the skin weight significantly $(\mathrm{p}<0.004)$ and kidney fat weight $(\mathrm{p}<0.067)$, while dressing percentage and other carcass indices were not significantly $(p>0.05)$ affected. It was concluded that BPM can completely (to $100 \%$ ) replace FM and GNC in the diet of growing rabbits. BPM also reduced kidney fat content (which is an index of carcass fatness). BPM can be fed (up to $6.8 \%$ of the total diet) to 5 6 weeks old rabbits through finishing with no adverse effect on growth or carcass characteristics.

K ey words: Rabbit, feedstuff, microbes, carcass, performance 


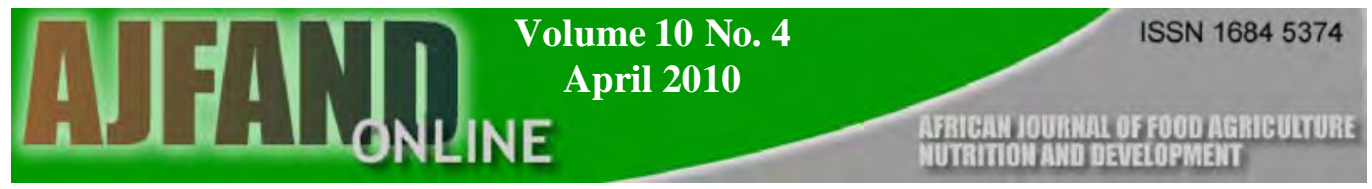

\section{INTRODUCTION}

The rearing of rabbits in developing countries has been widely seen as a means of poverty alleviation, and for supplying high quality protein to their teeming population, at an affordable price. Rabbit rearing for the rural and urban poor is a veritable means of producing high quality meat at a reasonable price to reduce the risk of protein malnutrition and other ailments associated with insufficient protein intakes in humans, especially in vulnerable groups, such as pregnant women and children. Rabbit meat, as a white meat, is also relished by health-conscious consumers, the elderly and people living with debilitating disease conditions due to its low fat and cholesterol contents. The feeding and nutrition of rabbits, however, requires that feed ingredients, which are the potential sources of nutrients need to be supplied in adequate quantity and quality for optimal growth rate. Rabbit feed should also be formulated on the basis of least cost ration formulation for sustainable livestock rearing and development. Rabbits like other monogastric species such as pigs and poultry, have no requirement for a specific feed ingredient, but can be fed on a wide range of nutrient sources as long as they are skilfully combined using optimised ration formulation techniques to meet the nutrient requirement for the various physiological stages of rabbit development.

Rabbit production in recent times has received a renewed attention as an alternative to poultry production due to the high cost of feed often associated with commercial poultry production and the incidence of bird flu, which makes poultry production unrealistic in some regions of the developing world [1]. Rabbits can thrive well on fibrous feed ingredients based on agro-industrial by-products, forages or a combination of both. The use of concentrate feed in rabbit production cannot be underestimated, because of the difficulty of accessing a steady forage supply by the backyard rabbit raisers in urban areas (mostly raised for family high quality dietary protein and supplemental income), difficulty in obtaining forage for rabbits during scarcity in the dry season of the year when forages are dried up and the slow growth and turnover rates accompanying sole forage feeding. Sole forage feeding may result in low level of nutrient intakes and sometimes below the nutrient requirement of rabbits. Nutrient deficiencies usually occur when concentrate feeds or household left-over foods are not supplemented (household left-over food supplementation may be unrealistic depending on the number of breeding female rabbits kept or the scale of operation). Feeding rabbits with concentrate feeds, as supplemental or sole feed requires the use of a combination of nutrient sources that can supply amino acids and other nutritional requirement of these animals. Animal protein (fish meal and blood meal) and vegetable protein (oil cake seeds) sources are mostly used as protein sources in rabbit feed [2]. Bacterial protein meal has the potential to serve as an alternative protein source to fish meal, blood meal and other plant protein sources for rabbit feeding. Bacterial protein meal (BPM) is a fermentation product produced from growing bacteria on natural gas, ammonia and mineral salts [3]. The bacterial biomass is mainly Methylococcus capsulatus, Ralstonia sp., Brevibacillus agri and Aneurinibacillus 


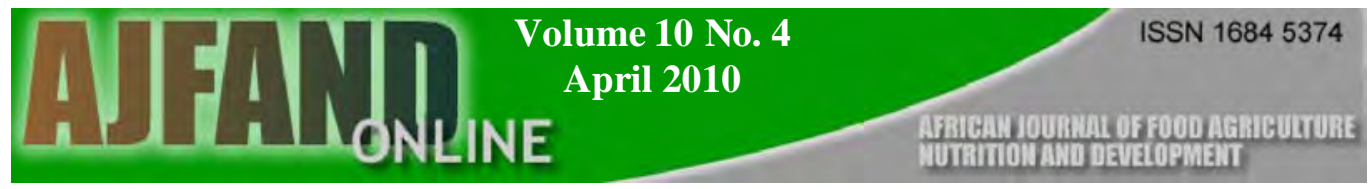

sp. Other important bacterial mixtures for the production of BPM include Alcaligenes acidovorans, Bacillus brevis and Bacillus firmus [3, 4, 5].

The dried microbial product consists of $70 \%$ crude protein, $10 \%$ crude fat and $7 \%$ crude ash) [6]. BPM can supply up to $40 \%$ of dietary nitrogen requirement in growing-finishing pigs [7], 40\% of dietary nitrogen in Atlantic salmon [8] and $33 \%$ of dietary nitrogen in broiler chicken [9] without any adverse effect on growth performance. However, increasing the BPM diet up to $48 \%$ of dietary nitrogen in piglets resulted in reduced daily weight gain and increased feed to gain ratio, but this has been attributed to marginal lysine deficiency rather than the effect of BPM per se [4].

In an economic analysis on rabbit production in Indonesia, it was reported that the benefit to cost ratio (index of profitability) in rabbit production ranged from 1.42 to 3.55 [1]. The profit margin was dependent on whether rabbits were solely fed on concentrate or a ratio of one to one of forage and concentrate and the breeding objective in terms meat production, meat and fur production, fancy (rabbit as pet) or laboratory use [1]. This picture may not be too different from what can be obtained in rabbit production in Nigeria based on diets formulated using mostly agro-industrial bye-products, although rabbits are mainly kept for meat production in Nigeria [10]. The use of concentrate feed as sole or supplemental feed for rabbit production, guarantees commensurate economic returns. This makes evaluation of alternative protein and energy sources necessary to broaden the database for rabbit feeding and to further study their inclusion levels for optimal growth rate in this species. The feeding value of BPM as a protein source for rabbits is not known and the BPM based on Streptomyces sp. has not been widely evaluated in animal studies including poultry and pigs. The objective of the present study was to determine the feeding value of BPM as a replacement for either fish meal or groundnut cake by evaluating the growth performance and carcass quality of growing rabbits fed graded levels of bacterial protein meal in diets largely based on agro-industrial by-products.

\section{MATERIALSAND METHODS}

This experiment was conducted at the Rabbit Unit of the Teaching and Research Farm, Obafemi Awolowo University, Ile-Ife, Nigeria.

\section{Diet preparation}

A control diet was formulated to meet the nutrient requirements of growing rabbits using National Research Council recommendation as a guide [11]. The control diet was based on palm kernel meal, maize, groundnut cake (GNC) and fish meal (FM). The control diet was fortified with lysine and methionine to optimize amino acid balance. Bacterial protein meal (BPM, Biogro ${ }^{\circledR}$ Super- Dried Streptomyces sp., species information not available from the manufacturer, Dawes Laboratories U.S.A) with crude protein $70.0 \%$, crude fat $6.50 \%$ and crude fibre 


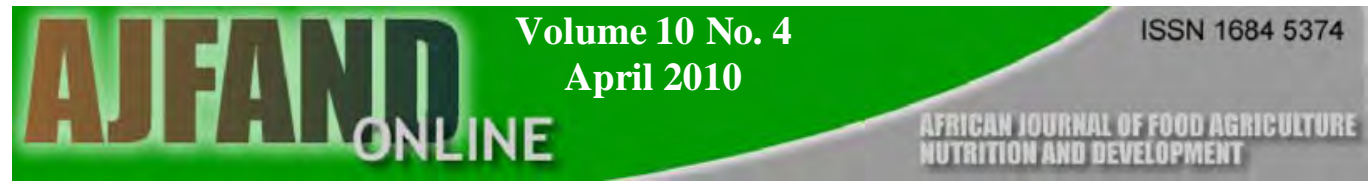

$4.05 \%$, was used in this experiment. Amino acid and other nutrients composition of diets was calculated based on previously published values $[12,13]$ and that of bacterial protein meal was based on the information leaflet from Dawes Laboratories, U.S.A. Table 1 shows the ingredient composition of the experimental diets. Bacterial protein meal replaced the fish meal in diets I, II and III in proportion of 0,20 and $40 \mathrm{~g} / \mathrm{kg}$ diet, respectively. Similarly, BPM replaced the groundnut cake meal (GNC) in the proportion of 34 and $68 \mathrm{~g} / \mathrm{kg}$ diet in diets IV and V, respectively. Table 2 shows the calculated values for amino acids on as fed basis. Replacement in all cases was based on nitrogen concentration. However, since a lower weight of BPM is required to replace GNC on nitrogen for nitrogen basis, corn bran was added to diets to make up to $100 \%$. Thus, the crude protein supplied by BPM as proportions of total protein present in feed (as $\%$ ) were $0,7.66,15.24,12.96$ and 25.64 in diets I, II, III, IV and V, respectively. All ingredients with the exception of the variable ones (FM, GNC, BPM and corn bran) were mixed as a single lot and later divided into five equal parts. Variable ingredients including the BPM were added separately in their respective proportions. Each diet was then mixed again and bagged.

\section{A nimal housing and management}

Twenty growing rabbits (mainly a heterogeneous population) of California White, New Zealand White and Chinchilla breeds of both sexes with average initial weight of 617.2 (s.e. 25) g and 5 - 6 weeks old were randomly assigned to five dietary treatments. Growing rabbits were weighed and uniformly distributed to their respective hutches based on sex and weight. Rabbits were divided into a group of 4 and each group (a treatment) consisted of two males and two females. Rabbits were individually housed in hutches with a dimension of $76 \mathrm{~cm} \times 62 \mathrm{~cm} \mathrm{x}$ $42 \mathrm{~cm}$ (Length $\mathrm{x}$ Breadth $\mathrm{x}$ Height) on wire screen floors. Each diet was offered ad libitum to the 4 rabbits and each rabbit was offered diets calculated to be above $4 \%$ body weight as dry matter intake. Feed was offered daily as meal, but usually moistened to prevent feed wastage. The daily feed supply was aimed at complete ingestion with minimal amount of left-over. The amount to be fed to prevent feed wastage and minimal residue was based on previous data collected on feed intakes on the same family of rabbits [14]. Remnant feed was taken out of the feeder and air dried. Left-over was then quantified and adjustment made for actual feed consumption. Feed supply was usually adjusted upwards on weekly basis based on the previous body weight changes. Feeds were formulated largely based on highly fibrous agro-industrial by-products optimised with approximately $17 \%$ of conventional feedstuffs for adequate nutrient supply to growing rabbits. This was in line with the principle of formulating least cost ration for rabbits for sustainable rabbit production and development. Diet formulation was aimed at achieving the $12 \%$ dietary fibre requirement of rabbits fed solely on a concentrate ration and to avoid the diarrhoea usually associated with low fibre intake in rabbits. Water was also provided unrestrictedly. Rabbits were individually weighed on weekly basis until the end of the experiment. Daily voluntary feed intakes were monitored. Feed intake and consequently feed conversion were calculated as treatment 
averages. The experiment lasted 84 days. At the end of the 12 weeks of feeding trial, 6 individuals from diets I and V (3 from each treatment) with similar body weight regardless of sex were selected, stunned and slaughtered for carcass evaluation. The head, the skin and all internal organs were removed. Hot carcass was weighed without any of these organs. Individual organs were excised and weighed separately. Individual rabbits from diets I and V were selected as opposed to the whole treatment groups to evaluate response in carcass characteristics for zero inclusion for BPM and highest level of BPM inclusion.

\section{Chemical and data analysis}

Dry matter, crude protein, crude fibre, ether extract and crude ash of BPM were determined according to the AOAC procedure [15]. Data collected from the growth study were subjected to Analysis of Variance (ANOVA) procedure using the software package SPSS 13.0 for windows. Data collected from carcass evaluation were subjected to an independent $t$ test using the same software. A linear regression on body weight changes of rabbits ( $\mathrm{y}, \mathrm{kg} / \mathrm{rabbit})$ depending on weeks (x, growth over time) was calculated. Similarly, data on feed intake (g/rabbit) depending on feeding period (weeks) were also fitted into a linear regression equation as given below.

$y=a+b x$

where $a=$ constant and $b=$ slope of the regression line.

Linear regression equation was calculated using GraphPad Prism 4.02 (GraphPad Software Inc., San Diego, California).

\section{RESULTS}

The proximate analysis of BPM was in good agreement with the declared values from the manufacturer and any differences were not beyond those of analytical error. Therefore, the analysed values were used for further calculation of the respective diets. Growing rabbits did not respond significantly $(p>0.05)$ to incremental BPM in feed intake, weight gain and feed conversion in the 84 days of experiment. The performance characteristics of growing rabbits fed bacterial protein meal either as a replacement for fish meal or groundnut cake meal is shown in Table 3 . There was no significant difference $(\mathrm{p}=0.9670)$ in feed intake amongst the various treatment groups. The average weekly feed intake (g/rabbit) over the period of 12 weeks was 367.96. The average weekly weight gain ( $\mathrm{g} / \mathrm{rabbit})$ in 84 days was similar $(\mathrm{p}=0.9718)$ between rabbits fed BPM as a replacement for FM as well as rabbits fed BPM as a replacement for GNC. Average daily weight gain (g/rabbit) ranged from 10.96 to 11.76 in diets I and V. Similarly, feed conversion ratio was not affected $(\mathrm{p}=0.8231)$ by incremental BPM supplementation and values ranged from 4.25 in diet V to 4.81 in diet II. 
Figures 1 and 2 show the body weight changes of growing rabbits depending on feeding period (weeks) fed BPM as replacements for FM and GNC, respectively. Estimated parameters for the linear regression of body weight changes and feed intakes of rabbits on the various dietary treatments are shown in Table 3.

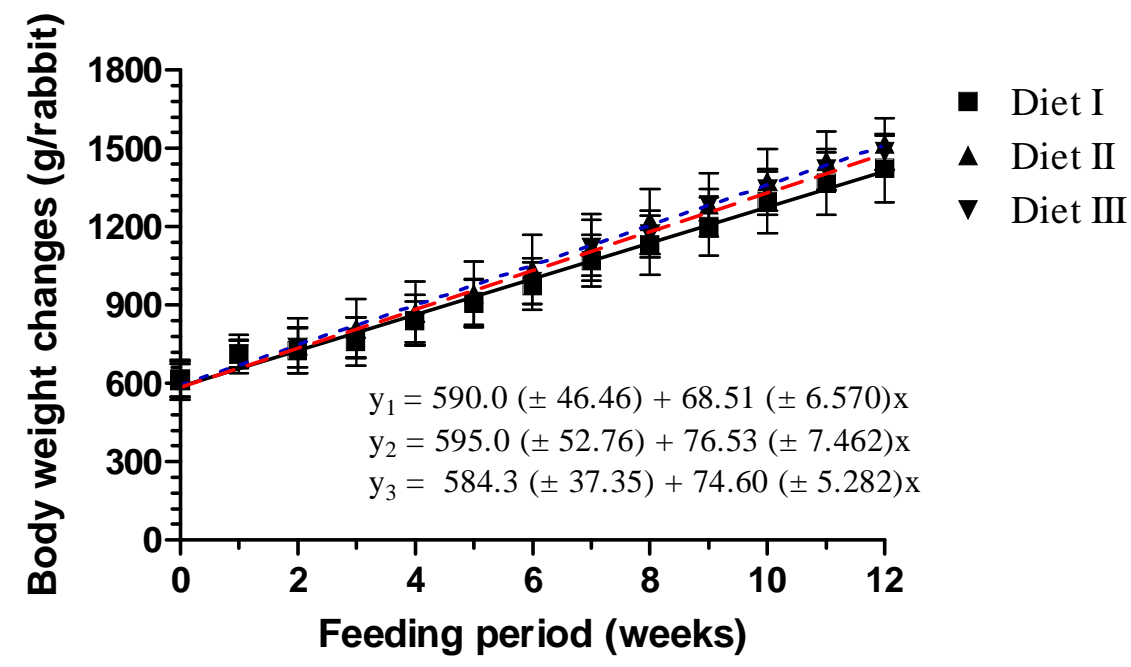

Figure 1: Body weight changes of growing rabbits fed bacterial protein meal as a replacement for fish meal in 84 days

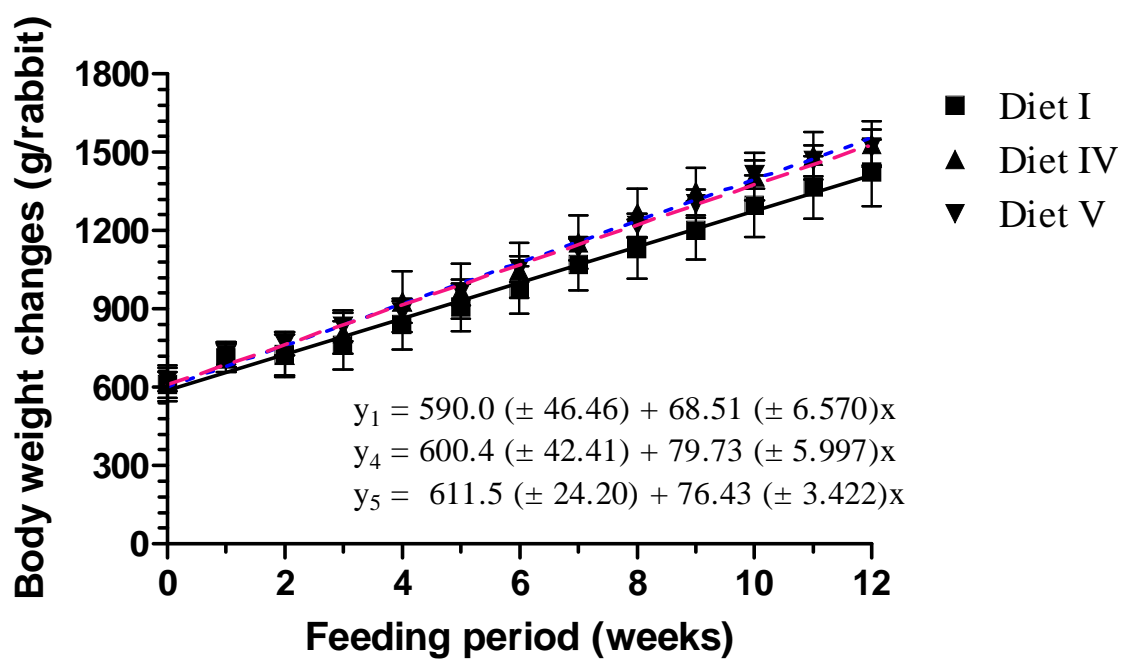

Figure 2: Body weight changes of growing rabbits fed bacterial protein meal as a replacement for groundnut cake meal in 84 days 


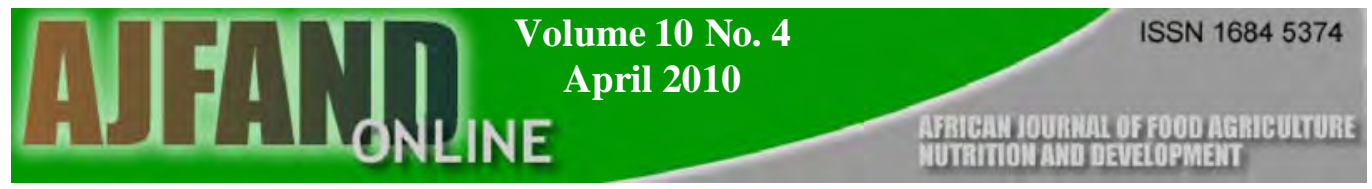

The linear model provided a good fit for the data as reflected in the parameter for goodness of fit ( $\mathrm{r}^{2}$ and Sy.x; Table 4). The slope of regression for body weight changes depending on weeks was highest in diet IV (79.73 g) and lowest in diet I $(68.51 \mathrm{~g})$. The parameters for the prediction equations for feed intake data are presented in Table 4. Increasing BPM concentration up to $68 \mathrm{~g} / \mathrm{kg}$ diet by complete replacement of GNC in diet V, compared to zero inclusion in diet I, resulted in reduced kidney fat weight $(\mathrm{p}<0.067)$, reduced skin weight $(\mathrm{p}<$ 0.004 ), reduced head weight (126.7 g vs. $133.3 \mathrm{~g}$ ), and reduced heart weight (3.9 g vs. $7.2 \mathrm{~g}$ ). All other carcass parameters were not significantly influenced by the supplementation of BPM (Table 5).

\section{DISCUSSION}

Supplementation of BPM either as a replacement for fish meal or groundnut cake meal resulted in no significant ( $p>0.05)$ decline in feed intake, body weight gain and feed conversion ratio. This implied that the nutrients contained in BPM, especially protein and its amino acid constituents were largely available to growing rabbits for productive purposes. The replacement of FM or GNC with BPM tended to enhance better growth rate and this further confirms the suitability of BPM as a feed resource that can be included in rabbit feed database or 'menu list'. This picture is also similar to those reported for pigs in which the replacement of soya bean meal with BPM up to $15 \%$ of the total diet resulted in no significant changes in feed intake, daily gain and feed conversion ratio [3]. The feed consumption, body weight gain and feed conversion in this experiment were in good agreement with those reported in literature for rabbits of similar weight range $[10,16]$.

The slope of regression of body weight changes depending on feeding period (weeks) can be construed to be the efficiency with which the ingested feed was used for growth. The graded supplementation of BPM from diets II to V tended to increase the slope of regression of body weight changes, depending on feeding period (weeks). The model fitted was able to explain 69 to $91 \%$ of the variation in body weight changes and 78 to $91 \%$ of the variation in feed intake. The slope of the regression curve of feed intake depending on the time of the experiment was also a reflection of the acceptability and palatability of BPM to growing rabbits, with the tendency to increase with BPM supplementation. This parameter is worth evaluating since feed intake is the primary determinant of nutrient supply. The acceptability of BPM to rats [17], pigs [3] and blue foxes [5] has been reported from other studies. Feeding of BPM to supply up to $79 \%$ of the dietary nitrogen requirement of rats had no negative effect on feed intake, growth rate and haematological values [17].

Increasing BPM concentration up to $68 \mathrm{~g} / \mathrm{kg}$ diet by complete replacement of GNC in diet V, compared to zero inclusion in diet I, resulted in reduced kidney 


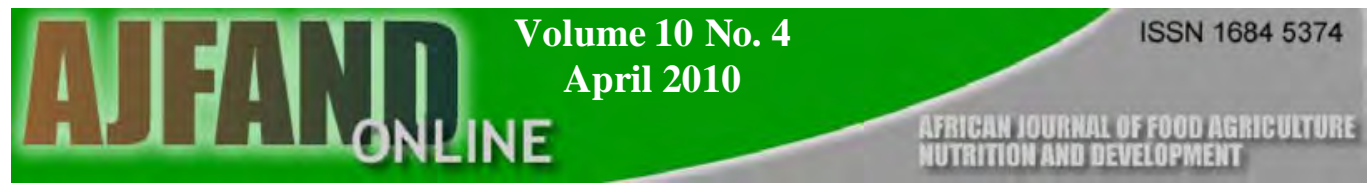

fat, skin, head and heart weights. The kidney fat weight is generally considered as an index of carcass fatness in rabbits [10]. The significant reduction in skin weight may be due to the reduction in adipose fat deposition. In selection of ducks for over eight generations for feed conversion efficiency, Pingel [18] reported a negative relationship between feed conversion ratio and carcass fatness. Ducks selected for low feed conversion had faster growth rate, lower feed conversion ratio and better efficiency of protein utilisation. This is in agreement with the present study, in which animals fed diet V, had better feed conversion ratio and lower carcass fatness. The reduced skin and kidney weight in rabbits fed BPM may also be attributed to the lower fat and energy contents of BPM compared to GNC. The BPM fed in the present study (according to the information provided by the manufacturer) contained $7.5 \%$ fat and $2400 \mathrm{Kcal} / \mathrm{kg}$ metabolisable energy, whereas GNC contained $6.5 \%$ fat and $3560 \mathrm{Kcal} / \mathrm{kg}$ metabolisable energy respectively [13]. However, other carcass indices such as dressing percentage, kidney weight, liver weight, stomach weight, lung weight and small intestine weight were not affected by BPM supplementation. This may imply that BPM does not contain any toxic substance that can cause hypertrophy of organs (usually due to overworking of these organs in an attempt to eliminate toxic feed components) or the level of BPM fed in the present study may not be sufficiently large enough to induce such a response. This observation is consistent with those made in pigs [4], in which feeding incremental levels of BPM ranging from 0 to $150 \mathrm{~g} / \mathrm{kg}$ in two studies, had no adverse effect on the dressing percentage of pigs slaughtered at commercial weight range. Similarly, feeding BPM as a replacement for soybean meal or fish meal up to $6 \%$ of the total diet in broiler chicken resulted in reduced abdominal fat pad and similar dressing percentage [19].

\section{CONCLUSION}

Results indicated that feeding bacterial protein meal up to $6.8 \%$ of the total diet to growing rabbit (approximately $26 \%$ of total crude protein requirement) had no adverse effect on diet acceptance or palatability, growth rate and tended to reduce feed conversion ratio. Also, feeding BPM resulted in reduced kidney fat weight (an index of carcass fatness), and by extension, reduced carcass fatness and had no adverse effect on dressing percentage and other carcass indices. It was concluded that BPM can serve as a high quality protein source for growing rabbit aimed at moderate to high growth rate and low carcass fatness. Future research should address the optimum levels of BPM inclusion for pregnant and lactating does. 


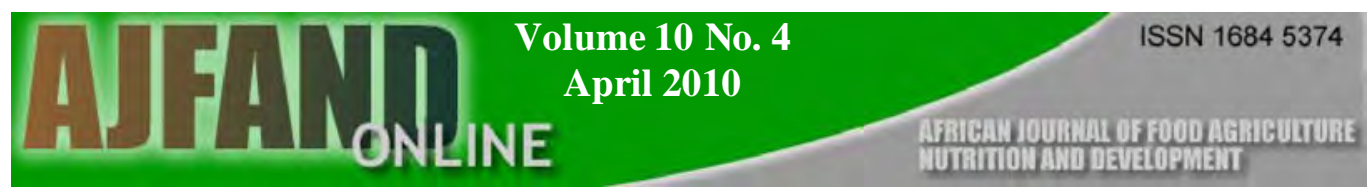

Table 1:Gross composition (\% ) of experimental diets fed to growing rabbits

\begin{tabular}{lrrrrr}
\hline Ingredients & \multicolumn{1}{c}{ Diet I } & \multicolumn{1}{c}{ Diet II } & Diet III & Diet IV & \multicolumn{2}{c}{ Diet V } \\
\hline Maize & 13.00 & 13.00 & 13.00 & 13.00 & 13.00 \\
Palm kernel meal & 52.30 & 52.30 & 52.30 & 52.30 & 52.30 \\
Groundnut cake meal & 10.00 & 10.00 & 10.00 & 5.00 & 0.00 \\
Fish meal & 4.00 & 2.00 & 0.00 & 4.00 & 4.00 \\
Bacterial protein meal & 0.00 & 2.00 & 4.00 & 3.40 & 6.80 \\
Rice bran & 7.75 & 7.75 & 7.75 & 7.75 & 7.75 \\
Cornbran & 9.90 & 9.90 & 9.90 & 11.50 & 13.10 \\
Bone meal & 2.00 & 2.00 & 2.00 & 2.00 & 2.00 \\
Salt & 0.50 & 0.50 & 0.50 & 0.50 & 0.50 \\
DL-Methionine & 0.10 & 0.10 & 0.10 & 0.10 & 0.10 \\
L-Lysine & 0.20 & 0.20 & 0.20 & 0.20 & 0.20 \\
Broiler premix & 0.25 & 0.25 & 0.25 & 0.25 & 0.25 \\
\hline Total & 100.00 & 100.00 & 100.00 & 100.00 & 100.00 \\
\hline
\end{tabular}

Table 2:Chemical composition (\%) of experimental diets fed to growing rabbits

\begin{tabular}{lrrrrr}
\hline Calculated composition & \multicolumn{1}{c}{ Diet I } & \multicolumn{1}{c}{ Diet II } & \multicolumn{1}{c}{ Diet III } & Diet IV & \multicolumn{2}{c}{ Diet V } \\
\hline Crude protein & 18.31 & 18.41 & 18.51 & 18.50 & 18.70 \\
Energy (kcal/kg) & 2556.15 & 2526.16 & 2496.15 & 2507.87 & 2459.59 \\
Crude fibre & 13.81 & 13.83 & 13.89 & 13.72 & 13.64 \\
Calcium & 0.73 & 0.72 & 0.71 & 0.83 & 0.92 \\
Phosphorus & 0.38 & 0.37 & 0.37 & 0.45 & 0.52 \\
Arginine & 1.60 & 1.53 & 1.45 & 1.34 & 1.08 \\
Histidine & 0.41 & 0.37 & 0.33 & 0.37 & 0.33 \\
Isoleucine & 0.65 & 0.59 & 0.53 & 0.58 & 0.51 \\
Leucine & 1.22 & 1.13 & 1.03 & 1.10 & 0.98 \\
Lysine & 0.78 & 0.72 & 0.67 & 0.79 & 0.79 \\
Phenyalanine & 0.73 & 0.79 & 0.85 & 0.82 & 0.91 \\
Sulphur containing amino acid & 0.60 & 0.61 & 0.63 & 0.66 & 0.73 \\
Threonine & 0.56 & 0.56 & 0.57 & 0.61 & 0.65 \\
Tryptophan & 0.15 & 0.14 & 0.13 & 0.14 & 0.13 \\
Valine & 0.87 & 0.80 & 0.73 & 0.78 & 0.69 \\
\hline
\end{tabular}




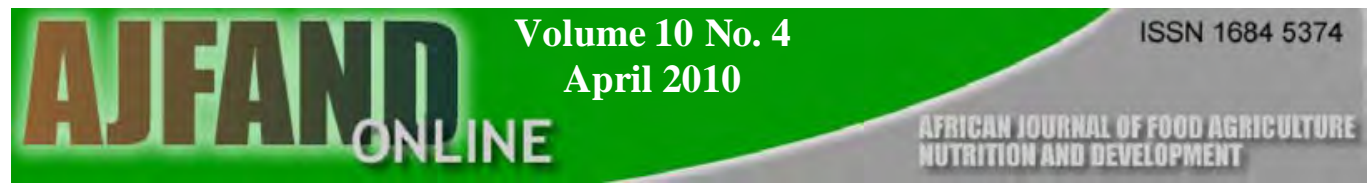

Table 3:Performance indices of growing rabbits fed incremental bacterial protein meal

\begin{tabular}{lccccccc}
\hline & Diet I & Diet II & Diet III & Diet IV & Diet V & Pooled SEM & P (ANOVA) \\
\hline $\begin{array}{l}\text { Feed intake } \\
\text { (g/rabbit/week) }\end{array}$ & 365.28 & 373.21 & 363.19 & 384.01 & 354.10 & 6.83 & 0.97 \\
$\begin{array}{l}\text { Initial body weight } \\
\text { (g/rabbit) }\end{array}$ & 610.79 & 614.68 & 617.30 & 620.61 & 622.50 & 24.72 & 0.99 \\
$\begin{array}{l}\text { Body weight gain } \\
\text { (g/rabbit/week) }\end{array}$ & 76.69 & 77.52 & 80.33 & 81.57 & 82.32 & 2.28 & 0.97 \\
$\begin{array}{l}\text { Feed conversion ratio } \\
(\mathrm{g} / \mathrm{g})\end{array}$ & 4.69 & 4.81 & 4.48 & 4.68 & 4.25 & 0.64 & 0.82 \\
\hline
\end{tabular}

Table 4: Estimated parameters for body weight changes and feed intake in growing rabbits fed incremental bacterial protein meal

\begin{tabular}{lllllc}
\hline & $\mathrm{a}$ & $\mathrm{b}$ & $\begin{array}{l}\text { 95\% Confidence } \\
\text { Interval of slope }\end{array}$ & $\mathrm{r}^{2}$ & Sy.x \\
\hline Body weight changes (g) & & & & & \\
Diet I & $590.01 \pm 46.46$ & $68.51 \pm 6.57$ & 55.30 to 81.72 & 0.69 & 177.31 \\
Diet II & $595.02 \pm 52.76$ & $74.60 \pm 7.46$ & 61.53 to 91.53 & 0.68 & 201.30 \\
Diet III & $584.30 \pm 37.35$ & $76.53 \pm 5.28$ & 63.98 to 85.22 & 0.80 & 142.51 \\
Diet IV & $600.40 \pm 42.41$ & $79.73 \pm 6.00$ & 67.67 to 91.78 & 0.78 & 161.82 \\
Diet V & $611.50 \pm 24.20$ & $76.43 \pm 3.42$ & 69.55 to 83.31 & 0.91 & 92.33 \\
Weekly feed intake (g) & & & & & \\
Diet I & $179.80 \pm 16.69$ & $28.54 \pm 2.26$ & 23.98 to 33.11 & 0.78 & 54.23 \\
Diet II & $184.70 \pm 18.64$ & $29.01 \pm 2.53$ & 23.91 to 34.11 & 0.74 & 60.57 \\
Diet III & $178.71 \pm 14.05$ & $28.39 \pm 1.91$ & 24.54 to 32.23 & 0.83 & 45.65 \\
Diet IV & $181.22 \pm 17.79$ & $31.19 \pm 2.42$ & 26.32 to 36.06 & 0.78 & 57.81 \\
Diet V & $178.60 \pm 10.20$ & $30.07 \pm 1.39$ & 27.28 to 32.87 & 0.91 & 33.13 \\
\hline
\end{tabular}

$\mathrm{a}=$ constant and $\mathrm{b}=$ slope of the regression line 


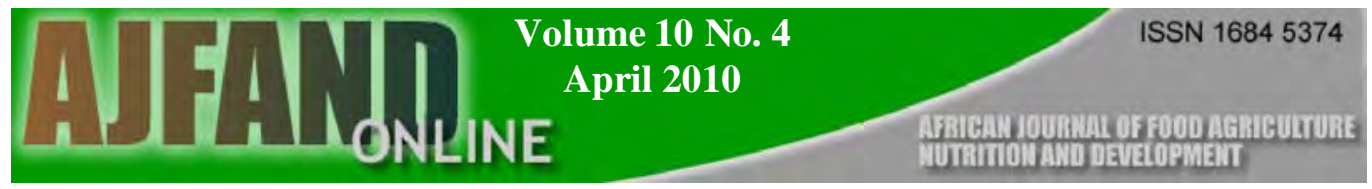

Table 5: Carcass characteristics of rabbits fed the control diet and the highest level of bacterial protein meal ( $n=3$ rabbits per treatment)

\begin{tabular}{lcccc}
\hline Parameter & Diet I & Diet V & Pooled SEM & p Value \\
\hline Live weight $(\mathrm{g})$ & 1540.00 & 1542.50 & 13.01 & 0.62 \\
Hot dressing $(\mathrm{g})$ & 759.08 & 755.73 & 6.42 & 0.17 \\
Dressing \% & 49.29 & 48.99 & 1.16 & 0.83 \\
Kidney weight $(\mathrm{g})$ & 8.18 & 8.11 & 0.21 & 0.78 \\
Liver weight $(\mathrm{g})$ & 50.14 & 50.14 & 1.75 & 0.99 \\
Stomach weight $(\mathrm{g})$ & 20.44 & 21.42 & 0.74 & 0.10 \\
Kidney fat weight $(\mathrm{g})$ & 22.01 & 17.86 & 2.38 & 0.07 \\
Head weight $(\mathrm{g})$ & 133.33 & 126.67 & 7.64 & 0.71 \\
Heart weight $(\mathrm{g})$ & 7.22 & 3.86 & 1.14 & 0.15 \\
Lung weight $(\mathrm{g})$ & 8.76 & 8.95 & 0.71 & 0.91 \\
Skin weight $(\mathrm{g})$ & $188.33^{\mathrm{a}}$ & $130.00^{\mathrm{b}}$ & 13.75 & 0.01 \\
Caecum weight $(1 \mathrm{~cm}$ length; g) & 0.93 & 0.98 & 0.11 & 0.83 \\
Small intestine (1 cm length; g) & 0.42 & 0.26 & 0.09 & 0.47 \\
\hline
\end{tabular}

${ }^{\mathrm{ab}}$ Means on the row with different superscripts are significantly different from each other $(\mathrm{p}<0.05)$. 


\section{REFERENCES}

1. Raharjo Y C Rabbit production development under bird flu situation in Indonesia. Proceedings MEKARN Rabbit Conference: Organic rabbit production from forages (Editors: R. Preston and N. Van Thu), Cantho University, $\quad$ Vietnam, 25-27 November 2008; http://www.mekarn.org/prorab/raha.htm Accessed on 06/03/2009.

2. Lebas F Reflections on rabbit nutrition with a special emphasis on feed ingredients utilization. Proceedings of the $8^{\text {th }}$ World Rabbit Congress, September 7-10, 2004, Puebla, Mexico Pp 686-736.

3. Hellwing ALF, Tauson A-H, Kjos NP and A Skrede Bacterial protein meal in diets for growing pigs: effects on protein and energy metabolism. Animal, 2007; 1: 45-54.

4. Øverland M, Kjos NP and A Skrede Effect of bacterial protein meal grown on natural gas on growth performance and carcass traits of pigs. Ital. J. Anim. Sci. 2004; 3: 323-336.

5. Skrede $A$ and $\varnothing$ Ahlstrøm Bacterial protein produced on natural gas: A new potential feed ingredient for dogs evaluated using the blue fox as a model. J. Nutr. 2002; 132: 1668S-1669S.

6. Skrede A, Berge GM , Storebakken T, Herstad O, Aarstad KG and F Sundstøl Digestibility of bacterial protein grown on natural gas in mink, pigs, chicken and Atlantic salmon, Animal Feed Science and Technology 1998; 76: 103-116.

7. $\varnothing$ verland $M$, Skrede $A$ and $T$ M atre Bacterial protein grown on natural gas as feed for pigs. Animal Science 2001; 51: 97-106.

8. Storebakken T, Baeverfjord G, Skrede A, Olli JJ and GM Berge Bacterial protein grown on natural gas in diets for Atlantic salmon, Salmo salar, in freshwater, Aquaculture 2004; 241: 413-425.

9. Skrede A, Schøyen HF, Svihus B and T Storebakken The effect of bacterial protein grown on natural gas on growth performance and sensory quality of broiler chickens. Can. J. Anim. Sci. 2003; 83: 229-237.

10. Odeyinka SM , Olosunde AS and OJ Oyedele Utilization of soybean milk residue, cowpea testa and corn starch residue by weaner rabbits. Livestock Research for Rural Development 19(9) 2007; http://www.cipav.orq.co//rrd// rrd19/9/odey19125.htm Accessed on 06/03/2009. 
11. National Research Council Nutrient Requirement of Rabbits Second Revised Edition, Washington, DC. National Academy Press; 1977.

12. Degussa A G Aminonec 1. 0. Net energy calculation tools for swine, Amino acid and more, Degussa AG, Frankfurt, Germany; 2005.

13. National Research Council Nutrient Requirements of Swine Tenth Revised Edition, Washington, DC. National Academy Press; 1998.

14. Fatufe $A A$ and I O M atanmi Evaluation of flamboyant seed meal as an alternative feedstuff (protein source) for rabbit feeding. Food, Health and Environmental Issues in Developing Countries: The Nigerian Situation. In Adebooye O. C., K. Taiwo and A. A. Fatufe. Cuvillier Verlag, Göttingen. ISBN-10: 3867277710 2008; 145 -152.

15. AOAC. Official Methods of Analysis. Association of Official Analytical Chemists, $15^{\text {th }}$ ed., Washington DC, USA; 1990.

16. Akinfala EO, Matanmi $O$ and $A O$ Aderibigbe Preliminary studies on the response of weaned rabbits to whole cassava plant meal basal diets in the humid tropics, Livestock Research for Rural Development 15 (4) 2003; http://www.cipav.org.co/lrrd/lrrd15/4/akin154.htm Accessed on 06/03/2009.

17. Al-awadh NM, Razzaque MA, J onker D, Banat IM and IY Hamda Nutritional and toxicological evaluation of single-cell protein produced from Bacillus sp. KISRI-TM1A in rats. Journal of Food Quality 1995; 18: 495-509.

18. Pingel $\mathrm{H}$ Selection for breastmeat percentage and feed conversion ratio in ducks. Proceedings of International Workshop on Waterfowl, 13.-15. November 2001, Halle/Wermsdorf, Martin-Luther University, HalleWittenberg, Germany; 2001.

19. Schøyen H F, Svihus B, Stor ebakken T and A Skrede Bacterial protein meal produced on natural gas replacing soybean meal or fish meal in broiler chicken diets. Archives of Animal Nutrition 2007; 61: 276 - 291. 